\title{
Phenotypic and genotypic characterization of plasmid-mediated AmpC beta-lactamases in enteric Gram-negative bacteria from patients with lower respiratory tract infections in a tertiary hospital, southwest Nigeria
}

\author{
${ }^{* 1,2}$ Thonda, O. A., ${ }^{2}$ Oluduro, A. O., ${ }^{3}$ Adewole, O. O., and ${ }^{4}$ Obiajunwa, P. O. \\ ${ }^{* 1}$ Department of Biological Sciences, Microbiology Unit, Kings University, Odeomu, Nigeria \\ ${ }^{2}$ Department of Microbiology, Faculty of Science, OAU, Ile-Ife, Nigeria \\ ${ }^{3}$ Department of Medicine, College of Health Sciences, OAU, Ile-Ife, Nigeria \\ ${ }^{4}$ Department of Paediatrics and Child Heath, Faculty of Clinical Sciences, OAU, Ile-Ife, Nigeria \\ Correspondence to: thondakemi22@gmail.com
}

\begin{abstract}
:
Background: AmpC or class $\mathrm{C}$ or group 1 beta lactamases are class $\mathrm{C}$ cephalosporinases that hydrolyse a wide variety of beta-lactam antibiotics including alpha methoxy beta-lactams (cefoxitin), narrow and broad spectrum cephalosporins. This study was conducted to characterize plasmid-mediated AmpC producing enteric Gramnegative bacteria from patients with lower respiratory tract infections in Obafemi Awolowo University Teaching Hospital Complex (OAUTHC) Ile Ife, Osun State, Nigeria

Methodology: A total of 149 patients with clinical features of lower respiratory tract infections (LRTI) were selected by simple random sampling for the study. All Gram-negative isolates recovered from standard microbiological cultures of respiratory specimens of these patients were tested against cefoxitin, third generation cephalosporins (3GCs), and other antibiotics using the disc diffusion AST method, and also screened for production of AmpC beta-lactamases phenotypically by the CLSI method. Plasmid DNA extraction was carried out on twenty-nine cefoxitin-resistant selected isolates using the Kado and Lin method, while genotypic detection of plasmid-mediated $A m p C$ gene was carried out by the polymerase chain reaction (PCR) assay.

Results: The results showed that $204(43.3 \%)$ of 471 isolates recovered from the 149 selected patients were resistant to 3GC in the AST assay, among which $121(59.3 \%)$ were resistant to cefoxitin, and 189 of the 471 isolates (40.1\%) were AmpC producers. The AmpC producers concurrently showed multiple resistance pattern to other antibiotics tested in this study. Ninety six percent of the 29 selected isolates for plasmid analysis contained plasmids, $45 \%$ of which amplified positive on PCR for CMY, 38\% for FOX, and 31\% for ACC types of AmpC genes. Conclusion: This study showed a high degree of antibiotic resistance among enteric Gram-negative bacteria recovered from patients with LRTIs, as well as high degree of plasmid-encoded AmpC genes responsible for this high antibiotic resistance among the isolates. Proper antibiotic policy and regulation are required to limit the spread of plasmid mediated AmpC $\beta$-lactamase producing organisms because they can lead to therapeutic failure in infected patients in the nearest future.
\end{abstract}

Keywords: Enteric Gram-negatives, AmpC beta-lactamase, plasmid, lower respiratory tract infection, PCR

Received Nov 18, 2020; Revised May 4, 2021; Accepted May 12, 2021

Copyright 2021 AJCEM Open Access. This article is licensed and distributed under the terms of the Creative Commons Attrition 4.0 International License $<$ a rel="license" href="http://creativecommons.org/licenses/by/4.0/", which permits unrestricted use, distribution and reproduction in any medium, provided credit is given to the original author(s) and the source. Editor-in-Chief: Prof. S. S. Taiwo

\section{Caractérisation phénotypique et génotypique des bêta-lactamases AmpC à médiation plasmidique dans les bactéries entériques Gram-négatives de patients atteints d'infections des voies respiratoires inférieures dans un hôpital tertiaire, sud-ouest du Nigéria}

\footnotetext{
*1,2Thonda, O. A., ${ }^{2}$ Oluduro, A. O., ${ }^{3}$ Adewole, O. O., et ${ }^{4}$ Obiajunwa, P. O.

${ }^{* 1}$ Département des sciences biologiques, Unité de microbiologie, Université Kings, Odeomu, Nigéria

${ }^{2}$ Département de microbiologie, Faculté des sciences, OUA, Ile-Ife, Nigéria

${ }^{3}$ Département de médecine, Collège des sciences de la santé, OUA, Ile-Ife, Nigéria

${ }^{4}$ Département de pédiatrie et de santé infantile, Faculté des sciences cliniques, OUA, Ile-Ife, Nigéria

*Correspondance à: thondakemi22@gmail.com
} 


\begin{abstract}
Abstrait:
Contexte: Les bêta-lactamases AmpC ou de classe $\mathrm{C}$ ou de groupe 1 sont des céphalosporinases de classe $\mathrm{C}$ qui hydrolysent une grande variété d'antibiotiques bêta-lactamines, y compris les alpha-méthoxy bêta-lactamines (céfoxitine), les céphalosporines à spectre étroit et large. Cette étude a été menée pour caractériser les bactéries à Gram négatif entériques produisant de l'AmpC à médiation plasmidique chez des patients atteints d'infections des voies respiratoires inférieures du complexe hospitalier universitaire d'Obafemi Awolowo (OAUTHC) Ile Ife, État d'Osun, Nigéria

Méthodologie: Un total de 149 patients présentant des caractéristiques cliniques d'infections des voies respiratoires inférieures (LRTI) ont été sélectionnés par échantillonnage aléatoire simple pour l'étude. Tous les isolats à Gram négatif récupérés à partir de cultures microbiologique standard d'échantillons respiratoires de ces patients ont été testés contre la céfoxitine, les céphalosporines de troisième génération (3GC) et d'autres antibiotiques en utilisant la méthode AST de diffusion sur disque, et également criblés pour la production de bêtalactamases AmpC phénotypiquement par le Méthode CLSI. L'extraction de I'ADN plasmidique a été réalisée sur 29 isolats sélectionnés résistants à la céfoxitine en utilisant la méthode Kado et Lin, tandis que la détection génotypique du gène $\mathrm{AmpC}$ à médiation plasmidique a été réalisée par le test de réaction en chaîne par polymérase (PCR).

Résultats: Les résultats ont montré que $204(43,3 \%)$ des 471 isolats récupérés des 149 patients sélectionnés étaient résistants à la 3GC dans le test AST, parmi lesquels $121(59,3 \%)$ étaient résistants à la céfoxitine et 189 des 471 isolats $(40,1 \%)$ étaient des producteurs d'AmpC. Les producteurs d'AmpC ont montré simultanément plusieurs profils de résistance à d'autres antibiotiques testés dans cette étude. Quatre-vingt-seize pour cent des 29 isolats sélectionnés pour l'analyse des plasmides contenaient des plasmides, dont $45 \%$ amplifiés positifs par PCR pour CMY, 38\% pour FOX et $31 \%$ pour les types $A C C$ des gènes AmpC.

Conclusion: Cette étude a montré un degré élevé de résistance aux antibiotiques parmi les bactéries entériques Gram-négatives récupérées chez des patients atteints de LRTI, ainsi qu'un degré élevé de gènes AmpC codés par plasmide responsable de cette résistance élevée aux antibiotiques parmi les isolats. Une politique et une réglementation appropriées en matière d'antibiotiques sont nécessaires pour limiter la propagation des organismes producteurs $\beta$-lactamase d'AmpC à médiation plasmidique car ils peuvent conduire à un échec thérapeutique chez les patients infectés dans un avenir proche.
\end{abstract}

Mots clés: Gram-négatifs entériques, $\mathrm{AmpC}$, bêta-lactamase, plasmide, infection des voies respiratoires inférieures, PCR

\section{Introduction:}

The resistance rate of multidrug-resistant (MDR) Gram-negative bacteria has increased continuously in the past few years, and bacterial strains that produce AmpC-type or class $C$ beta-lactamases and the extended spectrum beta-lactamases (ESBLs) are now of concern (1). However, the increased presence of plasmid-mediated AmpC beta-lactamases in the world is becoming of greater concern. Gram-negative organisms resistant to carbapenems or third generation cephalosporins due to ESBL production were defined as highly resistant isolates. However, strains resistant to two or more agents of the antimicrobial classes (e. g. quinolone and aminoglycoside) were also defined as highly resistant strains (2).

AmpC-type beta-lactamases are cephalosporinases that hydrolyze cephamycins as well as other extended-spectrum cephalosporins and are poorly inhibited by clavulanic acid. They are clinically significant because they confer resistance to groups of antibiotics such as cephalosporin, penicillin, cephamycin and monobactam. The $A m p C$ gene located on plasmids or chromosomes can be moved from one microorganism to another through transformation and conjugation. The presence of such genes on plasmids facilitates their spread between the family of Enterobacteriaceae (3). The AmpC enzyme-producing strains show broader and higher resistance, making them more challenging for physicians to treat associated infections by such strains.

There are two types of AmpC $\beta$ lactamases; plasmid-mediated (usually constitutive and rarely inducible) and chromosomal mediated (inducible). The chromosomal AmpC enzymes are communicated constitutively at a low level and are constantly found in bacteria such as Citrobacter freundii, Enterobacter cloacae, Morganella morganii, Hafnia alvei and Serratia marcescens. They are inducible normally by $\beta$-lactam antimicrobial agents such as cefoxitin and imipenem which are interceded by the $A m p R$ regulator. However, they are inadequately induced by the third or fourth generation cephalosporins $(4,5)$. Infections caused by AmpC producing bacteria are of particular clinical and epidemiological importance, and are often associated with high morbidity and mortality in infected patients $(6,7)$.

Plasmid-mediated AmpC beta-lactamases (PMACBL) have been found all over the world but are much less common than ESBLs $(5,8)$. Most strains of PMACBL have been isolated from patients after several days of hospitalization, but culture of the isolates from long-term care facilities, rehabilitation centers, and outpatient clinics have been reported $(9,10)$. Risk factors for bloodstream infection (BSI) caused by AmpC producing strains of Klebsiella pneumoniae and other enteric pathogens include prolonged hospital stay, care in an emergency unit, central venous 
catheterization, indwelling urinary catheter, and administration of broad spectrum cephalosporins and beta-lactamase inhibitors, which are similar risk factors for infections caused by ESBL producing $K$. pneumoniae strains $(5,11$, 12).

There is paucity of data on the prevalence of AmpC beta-lactamases among Gram negative isolates in Ile-Ife, Nigeria. Hence this study aimed to determine the prevalence and characterize AmpC producing Gram-negative enteric bacteria isolates from patients with lower respiratory tract infections (LRTI) in Obafemi Awolowo University Teaching Hospital Complex (OAUTHC) Ile-Ife, Nigeria.

\section{Materials and method:}

\section{Study setting, design and sampling}

Patients who reported at the Obafemi Awolowo University Teaching Hospital Complex (OAUTHC) chest clinic, adult emergency and chronic obstructive pulmonary disease (COPD) clinic with symptoms of lower respiratory tract infections were selected by simple random sampling and recruited for this study. Sputum and nasal swabs samples were collected aseptically from subjects between the period of January, 2015 and February, 2016. Sample size was determined using Cochran's formula (22).

\section{Ethical consideration}

Ethical approval was obtained from the Hospital Ethical and Research Committee of the institution. Informed consent of each subject was also obtained.

\section{Specimen collection, processing and bacterial isolation}

Sputum and nasal swabs of selected subjects with lower respiratory infections were collected into sterile universal bottles and sterile swab sticks respectively. The samples were cultured on cetrimide agar medium and MacConkey agar (Oxoid Ltd., Basingstoke, UK) and incubated aerobically at $37^{\circ} \mathrm{C}$ for $18-24 \mathrm{~h}$. Bacteria growth colonies on the culture plates were identified microbiologically using conventional methods (colonial morphology, Gram staining, and biochemical tests) according to Cheesebrough (13) and confirmed by the API 20E commercial identification kit.

\section{Antibiotic susceptibility test (AST)}

Antibiotic susceptibility testing (AST) was performed by the Kirby Bauer disc diffusion method. Mueller-Hinton (MH) agar plates were inoculated with 18-24 h culture inoculum of each bacterial isolate standardized with 0.5 McFarland standards. Single antibiotics discs (Oxoid, Basingstoke, Hampshire, England) of; cefotaxime $(30 \mu \mathrm{g})$, piperacillin $(10 \mu \mathrm{g})$, augmentin $(2 \mu \mathrm{g})$, cefoxitin $(30 \mu \mathrm{g})$, ceftazidime
$(30 \mu \mathrm{g})$, cefuroxime $(30 \mu \mathrm{g})$, ceftriaxone (30 $\mu g)$, ofloxacin $(5 \mu \mathrm{g})$, cefixime $(5 \mu \mathrm{g})$, imipenem $(10 \mu \mathrm{g})$, gentamicin $(10 \mu \mathrm{g})$, ciprofloxacin $(5 \mu \mathrm{g})$ and nitrofurantoin $(300 \mu \mathrm{g})$ were firmly placed on the surface of the inoculated $\mathrm{MH}$ agar plate using a sterile forcep. The plates were incubated aerobically in an inverted position at $37^{\circ} \mathrm{C}$ for $18-24 \mathrm{~h}$. The diameters of zone of inhibition of each bacterial isolate to each antibiotic disk on the culture plate was measured and compared with the Clinical and Laboratory Standards Institute (CLSI) guidelines (14) to determine resistivity or resistance of each isolate.

\section{Screening of AmpC production}

The primary screening of the AmpC enzyme-producing strains was conducted by the Kirby-Bauer disk diffusion method described by Kazemian (15). AmpC-producing bacteria were detected using FOX $(30 \mu \mathrm{g})$ drugsensitive disc according to the CLSI standards. A clear zone of $\leq 18 \mathrm{~mm}$ indicated strains producing AmpC enzyme (16).

\section{Extraction of plasmid DNA}

Plasmid DNA extraction was carried out according to the method of El-deeb (17), and Ganesh et al, (18). The plasmid DNA of 29 selected cefoxitin resistant Klebsiella isolates was extracted by suspending the bacterial cell in an Eppendorf tubes containing $1 \mathrm{ml}$ of sterile distilled water. The tube was then vortexmixed and centrifuged at 13,000 rpm for $5 \mathrm{~min}$ using BIO-RAD model $16 \mathrm{~K}$ micro-centrifuge, and the supernatant was decanted. A $200 \mu$ l of lysing solution (Tris buffer and $0.1 \%$ sodium dodecyl sulfate) was added to the pellet and the cell pellet was re-suspended completely to achieve complete lysis $(17,18)$. The cell pellet was incubated at $65^{\circ} \mathrm{C}$ for 30 minutes.

Phenol-chloroform (1:1) solution (200 $\mu \mathrm{l})$ was added to the pellet and mixed by inversion until complete emulsion is formed so as to precipitate the protein and to remove the cell debris (17). The tube was then centrifuged at high speed for 10 minutes. One hundred and fifty microliters $(150 \mu \mathrm{l})$ of the supernatant were transferred into a fresh tube and mixed well with $3 \mu \mathrm{l}$ of $5 \mathrm{M} \mathrm{NaCl}$ and $150 \mu$ l propanol was added to the tube to precipitate the DNA and mixed by inverting the tubes 3-5 times until the mixture became sticky. Samples were kept on ice for 20 minutes (to prevent them from the degradation of chromosomal DNA which may be co-precipitated with plasmid) and spinned at 12,000 rpm for 20 minutes and the supernatant was removed immediately. A $100 \mu \mathrm{l}$ of cold $80 \%$ ethanol was added to wash the DNA and spinned at $12000 \mathrm{rpm}$ for $3 \mathrm{~min}$, the supernatant was immediately removed. The pellet was then dried completely and resuspended in $30 \mu$ l of TE (Tris Ethylene diamine tetraacetate) buffer or distilled water and 
RNase (to degrade RNA) for further use. Purified plasmids were electrophoresed in $0.8 \%(\mathrm{w} / \mathrm{v})$ agarose for size estimation and pattern comparison. Plasmid DNA bands were visualized by UV-transilluminator, photographed with a Polaroid camera and documented using a gel electrophoresis documentation system. The molecular sizes of the unknown plasmid DNA were then estimated by comparing the distance travelled with that of the molecular weight of the standards $(17,18)$.

\section{Molecular detection of AmpC beta-lactamase genes by PCR assay}

The extracted plasmid DNA served as the PCR template. The genes encoding the PMACBL in cefoxitin-resistant Klebsiella isolates were detected by PCR technique (19). The PCR was performed using $25 \mu$ of AmpliTaq Gold PCR Master Mix (Applied Biosystems), $0.5 \mu \mathrm{M}$ of the forward and reversed primers for ACC-M-F-AACAGCCTCAGCAGCCGGTTA, ACCM-R-TTCGCCGCAATCATCCCTAGC (346bp), and CMY-F-TGGCCAGAACTGACAGGCAAA，CMY-RTTTCTCCTGAACGTGGCTGGC (462bp), $0.4 \mu \mathrm{M}$ of the primers for FOX-M-F-AACATGGGG TAT CAGGGAGATG, and FOX-M-R-CAAAGCGCGTA ACCGGATTGG (190bp) (20), and $2 \mu$ l of plasmid DNA template. The final reaction volume of $50 \mu \mathrm{l}$ was made up with sterile distilled water.

The amplification conditions were 10 min at $95^{\circ} \mathrm{C} ; 25$ cycles of $94^{\circ} \mathrm{C}$ for $30 \mathrm{~s}, 64^{\circ} \mathrm{C}$ for $30,72^{\circ} \mathrm{C}$ for $60 \mathrm{~s}$; and final extension of $72^{\circ} \mathrm{C}$ for 7 minutes. The amplicons were electrophoresed on $0.8 \%(\mathrm{w} / \mathrm{v})$ agarose, and bands were visualized with ultraviolet transilluminator and photographed using gene gel bioimaging system.

\section{Statistical analysis}

The data obtained were analysed using GraphPad Prism Version 6.01. The Chisquare test was used to test the significance of association of the variables with $p<0.05$ considered as significance value.

\section{Results:}

The baseline characteristics of the 149 patients are depicted in Table 1 . From the 471 isolates recovered, $40 \% \quad(189 / 471)$ were AmpC producers, with the most frequent isolates being Enterobacter sp (66.6\%, 42/63), followed by Yersinia sp $(60 \%, 6 / 10)$ and the least is Escherichia coli $(12.1 \%, 4 / 33)$ (Table $2)$. The isolates were most resistant to penicillins $(100 \%)$, cephems $(51.9 \%)$, beta-lactam inhibitors $(76.6 \%)$, and least resistant to fluoroquinolones $(4.4 \%)$ (Table 3$)$. The multiple antibiotic resistance (MAR) phenotypes of the bacterial isolates showed that diversities of MAR patterns occurred among the isolates of which $0.75 \%$ and $0.25 \%$ developed resistance to six and seven classes of antibiotics tested respectively, $5.5 \%$ developed resistance to five classes of antibiotics, $21.6 \%$ to four and $65.3 \%$ to three classes of antibiotics. All isolates exhibited different resistance profiles with "AMCR $/ A \cup G^{R} / P R L^{R "}$ appearing the most frequent.

Ninety-six percent ( $96 \%)$ of the selected cefoxitin resistant and AmpC producing Klebsiella $(n=29)$ isolates harboured single plasmid with molecular weight of $1300 \mathrm{bp}$. The PCR result showed that $13(45 \%)$ of the 29 isolates were positive for CMY gene, 11 (38\%) amplified for FOX gene while only 9 (31\%) amplified for ACC gene (Figs 1-3).

\section{Discussion:}

The results of the plasmid DNA analysis showed that the representatives multiple antibiotic resistant isolates harboured single plasmid. Ganesh et al., (18) reported similar single plasmid in $E$. coli. Plasmids are environmental and genetic factors that are highly mobile and can confer resistance genes on several classes of antimicrobials. The prevalence of plasmid-mediated AmpC type resistance is imperative to give helpful data and information expected to focused antimicrobial treatment and better disease control (21). The isolates were highly resistant to third generation cephalosporins including cefoxitin as previously reported by Thonda et al., (22). Reasons may be that the third generation cephalosporins antibiotics have been misused for a long period by individuals, therefore, over time the pathogens have developed resistance to these antibiotics (22).

In this study, $40 \%$ of the isolates were producers of PMACBL. AmpC production in these isolates could be due to a mechanism similar to that of ESBL producing organism that appear susceptible to ceftazidime by the disc diffusion method. This finding is similar to the study of Manchanda and Singh (23) who reported 39\% cefoxitin susceptibility in AmpC producers. Our study showed that not all cefoxitin resistant isolates possess plasmid AmpC $\beta$-lactamase gene by PCR assay. This finding agreed with the study of Fam et al., (24) and Yilmaz et al., (25) which reported that not all cefoxitin resistant isolates are AmpC $\beta$-lactamase producers. Firstly, the reason may be because cefoxitin resistance is not due to production of AmpC $\beta$-lactamase but also may be as a result of other enzymatic mechanism such as extended spectrum beta lactamases (ESBLs) and metallo beta-lactamase (MBL) or because of the non-enzymatic mechanism such as porin channel mutation (26). Another reason may be cefoxitin resistant phenotype in $E$. coli can result from overexpression of the chromosomal AmpC gene 
Table 1: Socio-demographic and clinical characteristics of patients with lower respiratory tract infections in Obafemi Awolowo University Teaching Hospital Complex (OAUTHC), Ile-Ife, Nigeria

\begin{tabular}{|c|c|}
\hline Characteristics & No of patients (\%) \\
\hline \multicolumn{2}{|l|}{ Gender: } \\
\hline Female & $61(40.9)$ \\
\hline Male & $88(59.0)$ \\
\hline \multicolumn{2}{|l|}{ Age group (years) } \\
\hline$\leq 10$ & $17(11.4)$ \\
\hline $11-20$ & $22(14.8)$ \\
\hline $21-30$ & $8(5.4)$ \\
\hline $31-40$ & $14(9.4)$ \\
\hline $41-50$ & $30(20.1)$ \\
\hline $51-60$ & $29(19.5)$ \\
\hline$>60$ & $29(19.5)$ \\
\hline \multicolumn{2}{|l|}{ Marital status: } \\
\hline Single & $21(14.0)$ \\
\hline Married & $128(85.9)$ \\
\hline \multicolumn{2}{|l|}{ Patient status: } \\
\hline Outpatients & $57(38.2)$ \\
\hline Inpatients & $92(61.7)$ \\
\hline \multicolumn{2}{|l|}{ Religion: } \\
\hline Christianity & $117(78.5)$ \\
\hline Islamic & $32(21.4)$ \\
\hline \multicolumn{2}{|l|}{ Occupation: } \\
\hline Farming & $24(16.1)$ \\
\hline Trading & $41(27.5)$ \\
\hline Civil servant & $18(12.0)$ \\
\hline Teaching & $11(7.3)$ \\
\hline Motor vehicle mechanics & $4(2.6)$ \\
\hline Others & $50(33.5)$ \\
\hline \multicolumn{2}{|l|}{ Occupational exposure: } \\
\hline Yes & $33(22)$ \\
\hline No & $116(78)$ \\
\hline \multicolumn{2}{|l|}{ Cough duration: } \\
\hline$<3$ months & $102(68)$ \\
\hline 3 months and above & $47(32)$ \\
\hline \multicolumn{2}{|l|}{ Smoking status: } \\
\hline Current & $4(2.6)$ \\
\hline Former & $27(18.1)$ \\
\hline Never & $118(79.1)$ \\
\hline \multicolumn{2}{|l|}{ Hospitals } \\
\hline OAUTHC & $131(87.9)$ \\
\hline SDAH & $16(10.7)$ \\
\hline Wesley, Ilesa & $2(1.3)$ \\
\hline
\end{tabular}

Table 2: Prevalence and distribution of AmpC producing enteric Gram-negative bacteria isolates in Obafemi Awolowo University Teaching Hospital Complex (OAUTHC), Ile-Ife, Nigeria

\begin{tabular}{ccc}
\hline Isolated Organism & $\begin{array}{c}\text { No of isolates } \\
\text { resistant to 3GC }\end{array}$ & $\begin{array}{c}\text { No of AmpC positive Isolates } \\
(\%)\end{array}$ \\
\hline Enterobacter $\mathrm{sp}(\mathrm{n}=63)$ & 21 & $42(66.6)$ \\
Klebsiella sp $(\mathrm{n}=166)$ & 116 & $50(30.1)$ \\
P. aeruginosa $(\mathrm{n}=47)$ & 20 & $27(57.5)$ \\
Escherichia coli $(\mathrm{n}=33)$ & 29 & $4(12.1)$ \\
Serratia sp $(\mathrm{n}=20)$ & 13 & $7(35)$ \\
Aeromonas $\mathrm{sp}(\mathrm{n}=29)$ & 16 & $13(44.8)$ \\
Citrobacter $\mathrm{sp}(\mathrm{n}=37)$ & 25 & $12(32.4)$ \\
Salmonella $\mathrm{sp}(\mathrm{n}=32)$ & 17 & $15(46.9)$ \\
Providencia $\mathrm{sp}(\mathrm{n}=4)$ & 3 & $1(25)$ \\
Yersinia $\mathrm{sp}(\mathrm{n}=10)$ & 4 & $6(60)$ \\
Shigella $\mathrm{sp}(\mathrm{n}=28)$ & 16 & $12(42.9)$ \\
Total $(\mathbf{n}=\mathbf{4 7 1})$ & $\mathbf{2 0 4}(\mathbf{4 3 . 3})$ & $\mathbf{1 8 9 ( 4 0 . 1 )}$
\end{tabular}

$3 \mathrm{GC}=3^{\text {rd }}$ generation cephalosporins 
Table 3: Antibiotic resistance (\%) of bacterial isolates from patients with lower respiratory tract infections

\begin{tabular}{|c|c|c|c|c|c|c|c|}
\hline 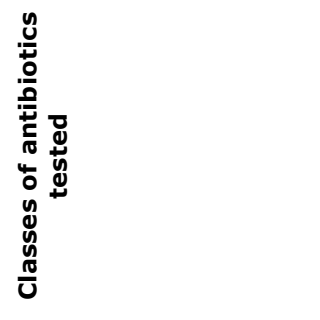 & 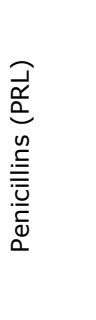 & 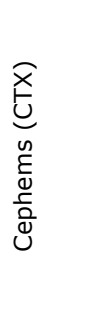 & 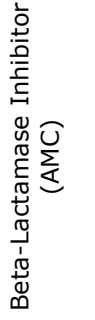 & 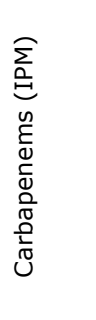 & 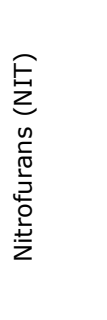 & 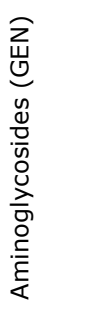 & 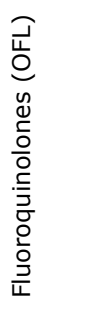 \\
\hline $\begin{array}{c}\text { Percentage resistance } \\
(\%)\end{array}$ & 100 & 51.9 & 76.6 & 4.4 & 15.9 & 12.3 & 3.92 \\
\hline
\end{tabular}

Piperacillin-PRL, Cefotaxime-CTX, AMC-Amoxicillin-clavulanic acid, Imipenem-IPM, Nitrofurantoin-NIT, Ofloxacin-OFL, Gentamicin-GEN

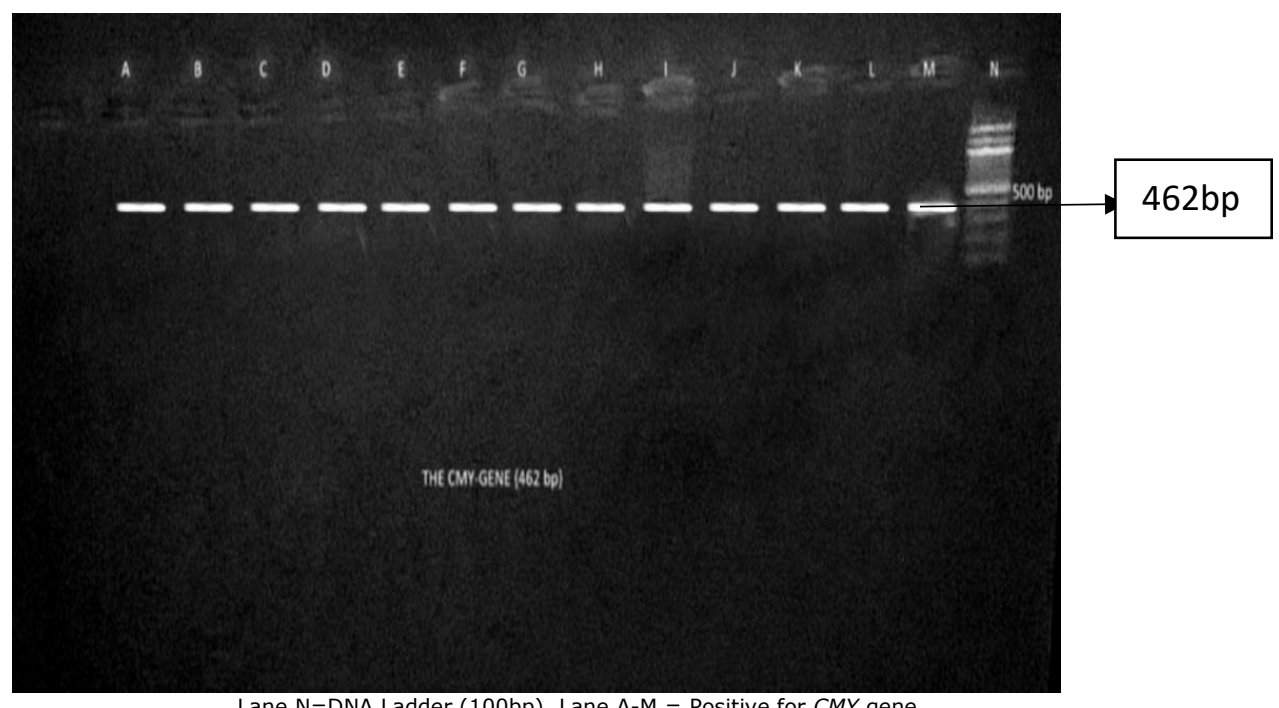

Lane $\mathrm{N}=\mathrm{DNA}$ Ladder (100bp), Lane A-M = Positive for CMY gene

Fig 1: Agarose gel electrophoresis of the amplification product coding CMY gene (462bp) in selected multiple antibiotic resistant Klebsiella Isolates

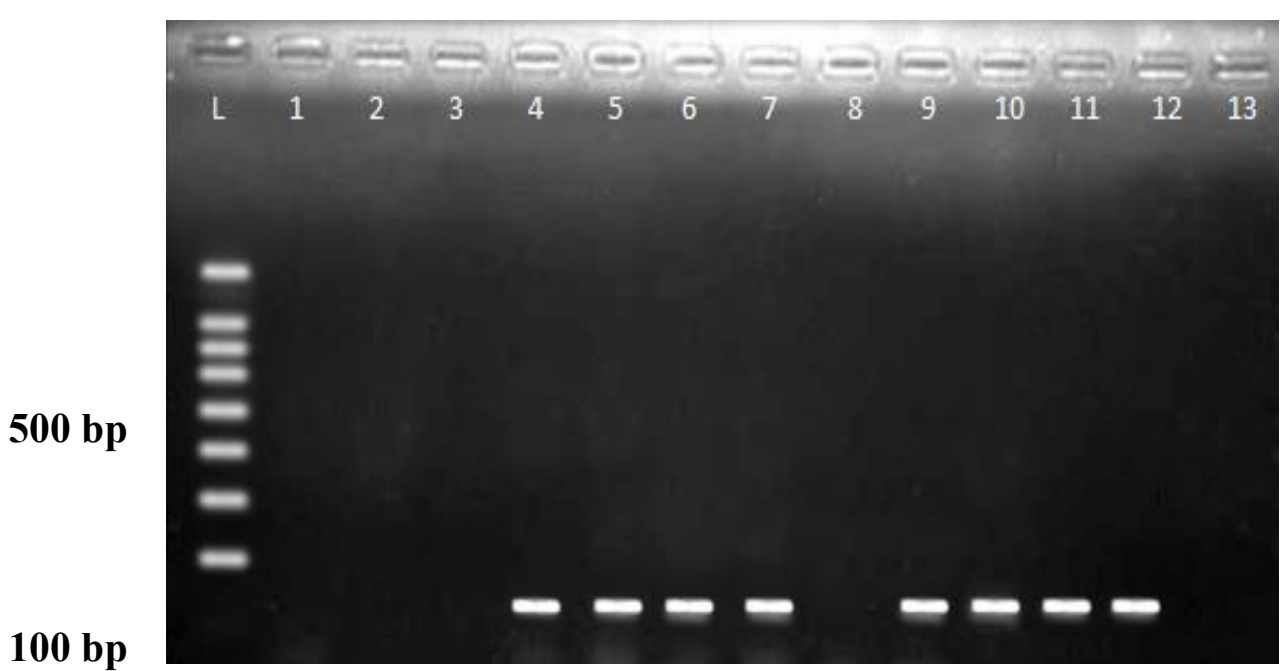

Lane L=DNA Ladder (100bp), Lane 1-13 = Positive for FOX gene

Fig 2: Agarose gel electrophoresis of the amplification product coding FOX gene (190bp) in selected multiple antibiotic resistant Klebsiella Isolates 


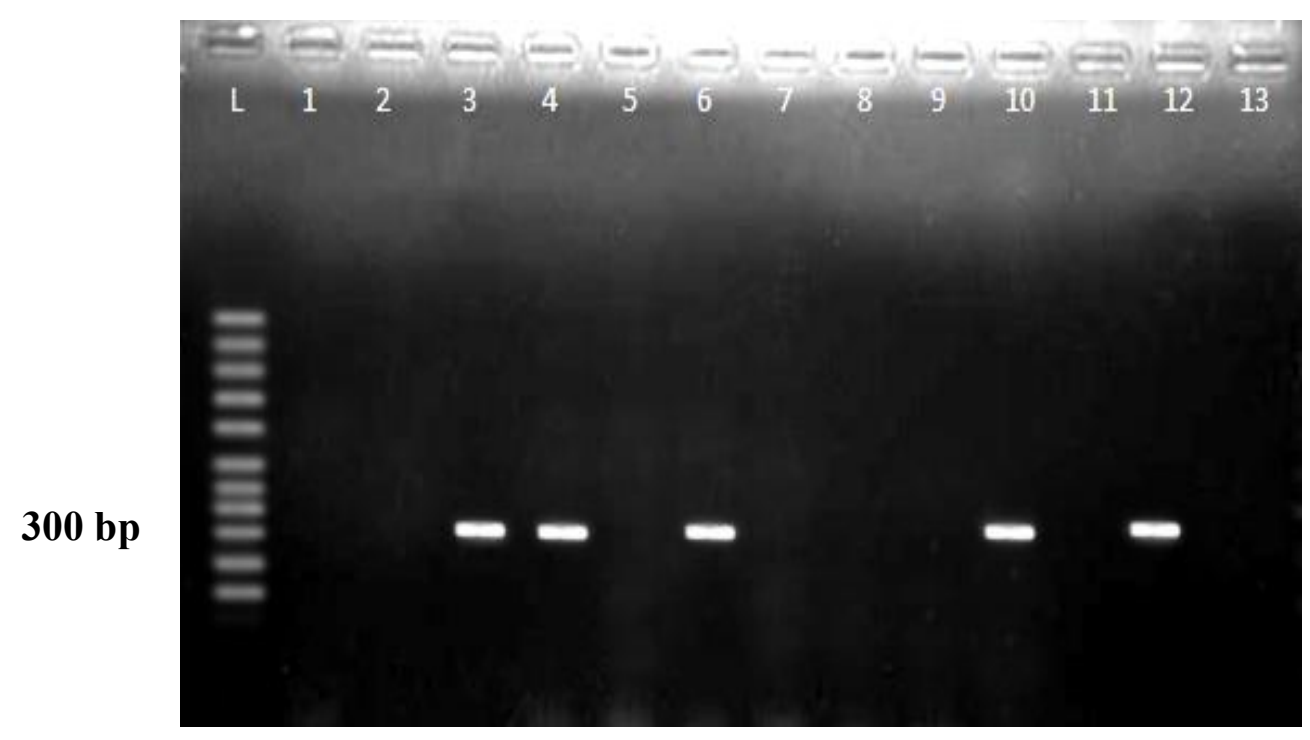

Lane L=DNA Ladder (100bp), Lane 1-13 = Positive for ACC gene

Fig 3: Agarose gel electrophoresis of the amplification product coding ACC gene (346bp) in selected multiple antibiotic resistant Klebsiella isolates

because of mutations that could occur in the promoter and attenuator regions (27). Cefoxitin has been demonstrated as a substrate to active efflux pump in clinical isolates (28). Genes for AmpC beta-lactamases are commonly found among members of the family Enterobacteriaceae including Enterobacter sp, Shigella, Providencia, Citrobacter freundii, Morganella morganii, Serratia marcescens and E. coli.

In this study, PCR revealed CMY genes to be the most prevalent among the $A m p C$ genes. The prevalence rate was similar to the study of Soha and Lamina (5), which reported Klebsiella sp to be $44 \%$ AmpC producers, but much lower than the study of Wassef et al., (39), which reported that $26.9 \%$ harboured the plasmid-mediated $A m p C$ gene and that of Yilmaz et al., (25) who reported that 3.6\% $\mathrm{K}$. pneumoniae were AmpC-producing strains. The molecular detection of plasmid-mediated $A m p C$ using PCR techniques showed that the most prevalent $A m p C$ gene belongs to family CMY which was detected in $40 \%$ of all selected isolates tested while FOX and $A C C$ genes were $33 \%$ and $27 \%$ respectively. Cefoxitin resistance in non-AmpC producers could be due to some other resistance mechanism(s). Hernandez-Alles et al., (30) have demonstrated the interruption of a porin gene by insertion sequences which could be a common type of mutation which causes loss of porin expression and high cefoxitin resistance in $K$. pneumoniae.

The results of the present study indicate that screening should include all the clinical isolates showing resistance to any of the cephalosporins irrespective of their cefoxitin susceptibility status. Plasmid-mediated
AmpC beta-lactamases may have arisen through the transfer of chromosomal genes for the inducible AmpC beta-lactamases onto plasmids. This transfer has resulted in plasmidmediated $A \mathrm{mpC}$ beta-lactamases in isolates of E. coli, K. pneumoniae, Salmonella sp, Citrobacter freundii, Enterobacter aerogenes and Proteus mirabilis. AmpC beta-lactamase producing bacterial pathogens may cause a major therapeutic failure if not detected and reported in time.

\section{Conclusion:}

In our study, the prevalence of AmpC beta-lactamase resistance is high among patients with respiratory infection and who had prior exposure to antibiotics. Detection and identification of types of PMACBL producing organisms is also important to ensure effective therapeutic intervention and optimal clinical outcomes so as to aid in hospital infection control and to help the clinicians to prescribe the most appropriate therapeutic agents, thereby decreasing the selective pressure, which generates antibiotic resistance.

\section{Conflict of interest:}

Authors declare no conflict of interest

\section{References:}

1. National Nosocomial Infections Surveillance (NNIS) System Report, data summary from January 1992 through June 2004, issued October 2004. Am J Infect Contr. 2004; 32: 470-485

2. Kluytmans-Vandenbergh, M. F., Kluytmans, J. A., and Voss, A. Dutch guideline for preventing nosocomial transmission of highly resistant 
microorganisms (HRMO). Infection. 2005; 33: 309-313.

3. Mai, M. H., and Reham, W. Phenotypic and Molecular Characterization of Plasmid Mediated AmpC $\beta$-Lactamases among Escherichia coli, Klebsiella spp., and Proteus mirabilis Isolated from Urinary Tract Infections in Egyptian Hospitals. Biomed Resource Int. 2014; 171548.

4. Philippon, A., Arlet, G., and Jacoby, G. A. Plasmid determined AMP C-type beta lactamases Antimicrob Agents Chemother. 2002; 46: 1-11.

5. Soha, A. E., and Lamiaa, A. A. Occurrence and detection of $A m p C$ b-lactamases among Enterobacteriaceae isolates from patients at Ain Shams University Hospital. Egypt J Med Hum Gen. 2015; 16: $239-244$.

6. Livermore, D. M. Current epidemiology and growing resistance of Gram-negative pathogens, Korean J Intern Med. 2012; 27(2): 128-142.

7. Maina, D., Revathi, G., Kariuki, S., and Ozwara, $\mathrm{H}$. Genotypes and cephalosporin susceptibility in extended spectrum beta-lactamase producing Enterobacteriaceae in the community. J Infect Dev Ctries. 2012; 6(6): 470-477.

8. Jacoby, A. G. AMP C $\beta$-lactamases. Clin Microbiol Rev. 2009; 22(1): 161-182.

9. Hanson, D., Moland, E. S., Hong, S. G., Propst, K., Novak, D. J., and Cavalieri, S. J. Surveillance of community-based reservoirs reveals the presence of CTX-M imported AMP C, and OXA-30 $\beta$-lactamases in urine isolates of Klebsiella pneumoniae and Escherichia coli in a US community, Antimicrob Agents Chemother. 2008; 52: 3814-3816.

10. Migliavacca, R. Nucle, E. D'Andrea, M. M. Spalla, M., Giani, T., and Pagani, L. Acquired AMP C type beta lactamases: an emerging problem in Italian long term and rehabilitation facilities. New Microbiol. 2007; 30: 295-298.

11. Pai, H, Kang, C. I., Byeon, J. H., et al. Epidemiology and clinical features of bloodstream infections caused by AMP C-type- $\beta$-lactamaseproducing Klebsiella pneumoniae. Antimicrob Agents Chemother. 2004; 48: 3720-3728.

12. Yan, J. J., Ko, W. C., Wu, J. J., Tsai, S. H., and Chuang, C. L. Epidemiological investigation of bloodstream infections by extended spectrum cephalosporin resistant Escherichia coli in a Taiwanese teaching hospital. J Clin Microbiol. 2004; 42: 3329-3332.

13. Cheesebrough, $M$. District laboratory practice in tropical countries" Part 2. 2nd ed. New York: Cambridge University Pres. 2010.

14. Clinical and Laboratory Standards Institute (CLSI). Performance Standards for Antimicrobial Susceptibility Testing. 29th ed. CLSI supplement M100. Wayne, PA: Clinical and Laboratory Standards Institute. 2015.

15. Kazemian H., Heidaric H., Ghanavatid, R., et al. Phenotypic and Genotypic Characterization of ESBL-, AmpC-, and Carbapenemase-Producing Klebsiella pneumoniae and Escherichia coli Isolates. Med Princ Pract. 2019; 28: 547-551

16. Coudron, P. E. Inhibitor-based methods for detection of plasmid-mediated AMP C betalactamases in Klebsiella spp., Escherichia coli and Proteus mirabilis. J Clin Microbiol. 2005; 43: 4163-4167.

17. El-deeb, B. A. Plasmid- and ChromosomeMediated Assimilation of Phenol and Cyanide in
Pseudomonas sp. strain PhCN. J Microbiol Biotechnol. 2006; 16(7): 1068-1077.

18. Ganesh, V., Suresh, K., and Sanjeev, K. S. Isolation and Characterization of Plasmid DNA from clinically isolated $E$. coli strain at Pravara rural Hospital, Loni, India. Int J Curr Sci. 2013; 7: 61-66.

19. Perez-Perez, F. J., and Hanson, N. D. Detection of plasmid mediated AmpC beta-lactamase genes in clinical isolates by using multiplex PCR. J Clin Microbiol. 2002; 40: 2153-2162.

20. Ogbolu, D. O., Terry Alli, O. A., Olanipekun, L. B., Ojo, O. I., and Makinde, O. O. Faecal carriage of extended-spectrum beta-lactamase (ESBL)producing commensal Klebsiella pneumoniae and Escherichia coli from hospital out-patients in Southern Nigeria. Int J Med Med Sci. 2013; 5 (3): 97-105.

21. Hanson, D. N. AmpC $\beta$-lactamases: what do we need to know for the future? J Antimicrob Chemother. 2003; 52: 2-4.

22. Thonda, O. A., Oluduro, A.O., and Osuntokun, O. $\mathrm{T}$. Prevalence of extended spectrum $\beta$ lactamases in multidrug resistant strains of Gram-negative bacteria. Afri J Microbiol Res. 2018; 12(7): 147-151.

23. Manchanda, V., and Singh, N. P. Occurrence and detection of AmpC $\beta$-lactamases among Gramnegative clinical isolates using a modified threedimensional test at Guru Tegh Bahadur Hospital, Delhi, India. J Antimicrob Chemother. 2003; 51: 415-418.

24. Fam, N. Gamal, D. El Said M., et al. Detection of plasmid-mediated AmpC beta-lactamases in clinically significant bacterial isolates in a research institute hospital in Egypt. Life Sci J. 2013; 10(2): 2294-2304.

25. Yilmaz, N. O. Agus, N. Bozcal, E. Oner, O., and Uzel, A. Detection of plasmid-mediated AmpC $\beta$ lactamase in Escherichia coli and Klebsiella pneumoniae. Indian J Med Microbiol. 2013; 31(1): 53-59.

26. Rawat, V., Singhai, M., Kumar, A., Jha, P. K., and Goyal, R. Bacteriological and resistance profile in isolates from diabetic patients. N Am J Med Sci. 2012; 4(11): 563-568.

27. Mulvey, M. R., Bryce, E., Boyd, D. A., OfnerAgostini, M., L. Simor, A. E., Paton, S., and the Canadian Hospital Epidemiology Committee, the Canadian Nosocomial Infection Surveillance Program, Health Canada "Molecular characterization of cefoxitin-resistant Escherichia coli from Canadian hospitals." Antimicrob Agents and Chemother. 2005; 49(1): 358-365.

28. Pages, J. M., Lavigne, J. P., Leflon-Guibout V., Marcon, E., Bert, F., Noussair, L., and NicolasChanoine, M. "Efflux pump, the masked side of $B$ lactam resistance in Klebsiella pneumoniae clinical isolates. PLoS One. 2009; 4 (3): e4817 https://doi.org/10.1371/journal.pone.0004817

29. Wassef, M., Behiry, I. M., Younan, M., El Guindy, N., Mostafa, S., and Abada, E. "Genotypic identification of AmpC $\beta$-lactamases production in Gram-negative Bacilli isolates. Jundishapur J Microbiol. 2014; 7(1), doi: 10.5812/jjm.8556.

30. Hernandez-Alles, S., Benedi, V. J., MartinezMartinez, L. Development of resistance during antimicrobial therapy caused by insertion sequence interruption of porin genes. Antimicrob Agents Chemother. 1999; 43: 937-939. 